\title{
The impact of physical activities on the development of the females' character
}

\author{
MILTIADIS PROIOS ${ }^{1}$, IOANNIS ATHANAILIDIS², EVGENIA GIANNITSOPOULOU1 \\ ${ }^{1}$ Department of Physical Education and Sport Science (TEFAA), Aristotle University of Thessaloniki, Greece \\ ${ }^{2}$ Democritus University of Thrace, Greece
}

\begin{abstract}
Proios M, Athanailidis I, Giannitsopoulou E. The impact of physical activities on the development of the females' character. J. Hum. Sport Exerc. Vol. 5, No. 3, pp. 485-494, 2010. Nowadays, the participation of females in exercise/ sport is unchallengeable. In addition, the established impacts of the above mentioned activities on females as well as on people in general are far too many. The present study, within the framework of a literature review, aims at the tracing of the impacts of participation in physical activities on the development of female character. The results of this review have revealed that physical activities affect some significant traits of personality, such as its pneumatic, moral and social qualities. The conclusion deriving from such a finding is that physical activities can constitute a means for the development of the females' character. Key words: FEMALES, EXERCISE, DEVELOPMENT CHARACTER.
\end{abstract}

Corresponding author. Aristotle University of Thessaloniki. latrou Zanna 17. 54643 Thessaloniki. Greece.

E-mail: mproios@phed.auth.gr

Submitted for publication February 2010.

Accepted for publication September 2010.

JOURNAL OF HUMAN SPORT \& EXERCISE ISSN 1988-5202

(C) Faculty of Education. University of Alicante

doi:10.4100/jhse.2010.53.18 


\section{INTRODUCTION}

Human by nature is a moving creature. The significance of movement through exercise in the development of the human beings has been stressed as early as the ancient times. Nowadays, the participation of females in physical activities (physical education, competitive and recreational activities) is unchallengeable (Giuliano, Popp, \& Knight, 2000), something that reveals the significance of exercise for humans. This is also evident by the fact that exercise, apart from its contribution to the improvement of the physical health of the individual (e.g., Daniels et al., 2005; Kellinske, Mayer, \& Chen, 2001), it plays a significant role in its social and psychological development as well (Shields \& Bredemeier, 1995, 2001; Weiss \& Smith, 2002).

The social and psychological traits constitute features of an individual's personality or character. These traits reveal cultural values, moral orientations and behaviors. More specifically, they enable us to comprehend the way in which such an individual tries to cope with his/her problems. Bredemeier and Shields (1998) maintained that the moral values as well as the attitudes and beliefs are the ones that reveal the moral content of someone's moral judgment.

The exhibition of proper behaviors (prosocial or sport) by individuals in sport, as well as in the greater social environment, is the subject of research nowadays. The present study, in the framework of a review of the to-date literature, will attempt to determine the factors developed by the participation in physical activities and at the same time contribute to the development of the females' character; and even more specifically, the factors affecting the pneumatic, moral and social qualities of females.

\section{DEVELOPMENT OF PNEUMATIC QUALITIES}

As pneumatic qualities can be considered a set of factors that contribute to the development of intellect and judgment of the individual. These qualities are related to the intellectual skills of the individual, while at the same time they qualify the human character. For instance, the character of an individual with developed pneumatic qualities/skills is qualified by discretion. The individual characterized by discretion reflects and makes positive remarks on another individual in order to honor the latter's character; in order, now, to jest this other individual, the former resolves to things that do not cause any annoyance (Aristotelis, 1949).

In the development of the pneumatic skills of an individual, and more specifically those of a female, the good physical condition, the psychological/ emotional and cognitive skill, in combination with the intellectual/mental health have their contribution. A set of empirical results presented below will support the above mentioned statement.

\section{Physical health}

Physical activity and sport are two factors that support the individuals' physical development (NFHS, 2002) and especially the health/ fitness of females (Harne \& Bixby, 2005; Kelinske, Mayer, \& Chen, 2001). Researches have established that the individuals exhibiting high levels of physical activity are also less liable to exhibit diseases, while they also exhibit limited negative effects in case of chronic diseases (e.g., Blair et al., 1984; Blair et al., 1989; Lee, 1994; Manson et al., 1991; Salonen et al., 1982). This can be considered as contributing to the development of the females' pneumatic skills, as they can take to the development of these skills rather undistracted. Characteristic are the results of a research which established that the females who participated in physical activities exhibit a more positive attitude towards life, a better perception of their role, they are characterized by intense empathy towards families and friends, they feel healthier and happier, and they anticipate hardships easier (Kull, 2002). 


\section{Psychological/emotional health}

The role of exercise and sport in the development of the psychological (e.g., Health Canada, 2003; NFHS, 2002) and emotional health (e.g., Health Canada, 2003; NFHS, 2002) is considered significant as well. Especially psychological health is considered to play a significant role in the establishment of a good life (Park, 2004). An individual can be psychologically healthy when it is characterized by inner equilibrium, something that can be achieved by means of better self-concept. Participation in physical activities and sport, due to the contact and cooperation developed among individuals, can shape a better self-concept, namely a better organization of the comprehensions that are accepted by their conscience (Rogers, 1951). The statement that the existence of psychological health (i.e. through self-concept) contributes to the development of pneumatic skills is supported by findings of studies which revealed that self-concept is directly related to school performance, professional choices and ambitions, as well as to behavioral aspects considered significant for the establishment of satisfactory interpersonal relations and the individual's heartsease (e.g., Markus \& Nurius, 1987; Wigfield \& Karpathian, 1991).

A form of female self-concept significantly improved by exercise is self-esteem (e.g., Hayes, Crocker, \& Kowalski, 1999; Young \& Bursik, 2000). Self-esteem is a global, self-evaluative personality disposition that reflects the degree to which an individual feels positive about the self (Carron, Hausenblas, \& Estabrooks, 2003). Another form of self-concept developed by participation in exercise and sport is self-confidence. This can contribute to the development of the pneumatic skills by developing personal competence (Feltz, Landers, \& Raider, 1979).

It is maintained that participation in exercise and sport also develops another psychological trait, namely empathy (Kalliopuska, 1992). Indeed, sport constitutes an environment that produces emotional experience and at the same time provides opportunities for developing empathic skills (Bredemeier \& Shields, 2006). The development of such a skill is even more evident in the case of females (e.g., Eagly \& Wood, 1991; Kalliopuska, 1987). Actually, many psychologists have argued that women (and girls) are generally more empathic or sympathetic than men (and boys) (Eagly \& Crowley, 1986).

\section{Cognitive skill}

The development of the cognitive skill by participating in sport is a result of intellectual health. This is due to the activation of several cognitive processes, such as teaching and learning. For instance, within the framework of physical activities, several types of games are performed ensuring different learning opportunities and teach different kinds of cognitive skills to both girls and boys. Thus, these processes can contribute to the cognitive development of the participants (Mize, 1991; Stevens, 1994). As concerning females, their cognitive characteristics have been maintained to be similar to those of males (Marcia \& Fridman, 1970; Prager, 1983).

As a result of the improvement of the cognitive skill in the context of sport, several types of values and attitudes are developed (e.g., Coakley, 1998; Sage, 1998). However, it is supported that the increase of sport experiences makes people consider winning more significant than fairness, with the boys being more intensely oriented towards this concept than girls (e.g., Sage, 1980; Webb, 1969).

Another result of the improvement of the cognitive skill of the participants in exercise/ sport is the amplification of academic performance (Dwyer et al., 2001; California Department of Education, 2002). Such an amplification seems to be more intense in the case of female athletes (Eitzen \& Sage, 1997). 
Nevertheless, findings of a study have maintained that the commercialization of college sport disorientates the participants from their academic commitment (Riemer, Beal, \& Achroeder, 2000), with females exhibiting similarities with males (Eitzen \& Sage, 1997).

In addition, the improvement of the cognitive skills in the context of exercise and sport leads to the exhibition of prosocial behaviors, such as cooperation (e.g., Mannell \& Kleiber, 1997; Wankel \& Berger, 1990), and empathy (e.g., Cote, 2002). More specifically, as concerning the virtue of empathy, it has been mentioned that women (and girls) are generally more empathic or sympathic than men (and boys) (Eagly \& Crowley, 1986). Additionally, the improvement of the cognitive skills can contribute to the learning of moral virtues. According to Shields and Bredemeier (1995), competitive sport can contribute to the development of virtues characterizing the individual. However, positive character building is maintained not to be automatically achieved by participating in sport (Gerdy, 2000; Hellison, 2003).

Finally, the improvement of the cognitive skills in the context of exercise/sport is the result of a good mental health (Camacho et al., 1991; Paluska \& Schwenk, 2000). The improvement of the cognitive skills contributes to the improvement of the cognitive functions, such as reaction time, memory, and fluid intelligence in older people (Boutcher, 2000; Etnier, 1997). Good mental health, as the result of participation in exercise/sport, establishes a positive mood, and a general concept of well-being (Stephens, 1988 ) in females, while limited participation in physical activities can lead to depressive symptoms (Farmer et al., 1988; Kull, 2002).

\section{DEVELOPMENT OF MORAL QUALITIES}

Undoubtedly, all human activities aim at bliss, which is the acquisition of happiness. Bliss, as any other good, can be achieved by the individual's performance of perfect actions. Achievement of bliss requires maturity and completion of life. These qualities lead to the performance of perfect actions, something that can reveal the existence of a virtue in the character of the performer. Virtue, as a moral quality, is based on volition. Yet, virtue becomes volition only if it is a constant quality (habit), a morale based on an axiom, something achieved only by a mature individual.

Many philosophers maintain that morality is also a form of virtue (Maclntyre, 1981; Noddings, 2002). The development of moral virtues is the subject of research in the present paper as well. Sport is the environment in which the development of virtues contributing to the improvement of character can be achieved (Shields \& Bredemeier, 2001). This is possible because participation in physical activities contributes to the development of cognitive and emotional maturity, as it has been previously maintained, something that effectively contributes to moral development (Telama, 1999). Results of a recent study have revealed the intermediary role that can be played by the psychological trait of self-esteem in exhibiting moral behaviors (Proios \& Balasas, 2007).

As concerning the gender-related differences in moral development, viewpoints are rather controversial. For instance, Abrahamsen and Roberts (2003), Guivernau and Duda (2002), Miller, Roberts, and Ommundsen (2005) maintained the existence of significant gender-related differences in moral reasoning, with the females exhibiting a higher level of moral reasoning than males. In addition, results of others studies established that females exhibit a higher sportspersonship orientation than males (Chantal \& Bernache-Assollant, 2003; Tsai \& Fun, 2005). On the contrary, the studies of Bredemeier (1994, 1995), Bredemeier and Shields (1984), and Proios, Doganis, and Athanailidis (2004) did not establish any significant gender-related difference concerning moral reasoning. 
Although the above mentioned findings support the statement that participation in sport helps the improvement of moral maturity of youth, the findings of some other studies revealed that sport has no impact in athletes (e.g., Bredemeier \& Shields, 1986; Proios, Doganis, \& Athanailidis, 2004). Thus, we conclude that indeed participation in sport in itself does not guarantee the prospective positive psychological results in the case of youths (Bredemeier \& Shields, 1995).

\section{DEVELOPMENT OF SOCIAL QUALITIES}

Society is determined as the uniform ensemble of individuals with specifically limited function. These limits of function in a human society are determined by common values and common culture within a specific geographical area, exhibiting unity and common conscience (common morals, customs or practices). This makes evident that the socialization of humans should be sought and directed so as the accession of the individual in a group to be held in harmony and in the proper way. This helps to avoid tension within the same group.

Sport constitutes part of a greater social group and at the same time it is an environment developing such qualities that support the socialization of individuals. More specifically, sport is a context in which youths have the opportunities to establish positive relations within groups, as well as to achieve completion, social status and social mobility within the community they live (Wankel \& Berger, 1990).

Some of the social qualities characterizing a socialized individual are the ability to cooperate with others, the respect showing each other, etc. Sport is maintained to enable the development of social skills such as cooperation, assertion, responsibility and commitment (Cote, 2002; Kleiber \& Roberts, 1981; Scanlan et al., 1993; Shogan, 1999; Telama, 1999; Weiss \& Smith, 2002).

In the framework of the development of cooperation, a better concept on mutualism or reciprocity is shaped, and generally the individuals' moral powers are developed and exercised (Rawls, 2001). Additionally, in the framework of cooperation within exercise and sport participation, a positive peer relationship is developed. Result of such a peer relationship is the development of friendship (e.g., Brustad, Babkes, \& Smith, 2001; Wright \& Cote, 2003) and peer acceptance (Greendorfer, 2002). Friendship, on its turn, develops companionship, self-esteem, mutual help and direction, while it contributes to the exhibition of positive prosocial behaviors. Girls are maintained to be more skilful than boys concerning the determination of emotional support as a positive feature of friendship in sport (Weinberg \& Gould, 2003). And although peer acceptance shapes perceptions of authority and views toward competition and compromise, it is also believed that it could affect views towards competition and cooperation, personal attitudes, and other psychological, social, and emotional outcomes (Sullivan, 1953).

The development of responsibility directs individuals to keep their promises and be fair in their transactions with others (Lickona, 1991). While, at the same time, in the framework of the development of the commitment skill, the individual develops leadings traits (e.g., Elley \& Kirk, 2002; Wright \& Cote, 2003), it exhibits sportspersonship behaviors (Shields \& Bredemeier, 1995) and perceives its own moral identity (Murray \& Mann, 2001). 


\section{REFERENCES}

1. ABRAHAMSEN FE, ROBERTS GC. Moral functioning in youth soccer. Proceeding of the Xth European Congress of Sport Psychology. Copenhagen, Denmark; 2003. Pp. 18. [Abstract] [Back to text]

2. ARISTOTELIS. Ethics Nikomachia. (Tran., A. Dalezios). Athens: Papiros; 1949. [Back to text]

3. BLAIR SN, GOODYEAR NN, GIBBONS LW, COOPER KN. Physical fitness and incidence of hypertension in healthy normotensive men and women. J Amer Med Assoc. 1984; 252:487-490. [Abstract] [Back to text]

4. BLAIR SN, KOHL HW, PAFFENBARGER RSJR, CLARK DG, COOPER KH, GIBBONS LW. Physical fitness and all-cause mortality. A prospective study of healthy men and women. $J$ Amer Med Assoc. 1989; 262:2395-2401. [Abstract] [Back to text]

5. BOUTCHER SH. Cognitive performance, fitness and ageing. In: SJH Biddle, KR Fox, SH Boutcher (Eds.). Physical activity and psychological well-being. London: Routledge; 2000. Pp. 118-129. [Back to text]

6. BREDEMEIER B, SHIELDS D. Game reasoning and interactional morality. The J Genetic Psych. 1986; 142:257-275. doi:10.1080/00221325.1986.9914499 [Back to text]

7. BREDEMEIER B, SHIELDS D. Moral assessment in sport psychology. In: JL Duda (Ed.). Advances in sport and exercise psychology measurement. Morgantown WV: Fitness Information Technology; 1998. Pp. 257-276. [Back to text]

8. BREDEMEIER B, SHIELDS D. Sports and character development. President's Council on Physical Fitness and Sport Res Digest. 2006; 7(1):1-8. [Full text] [Back to text]

9. BREDEMEIER B. Children's moral reasoning and their assertive, aggressive, and submissive tendencies in sport and daily life. J Sport \& Exerc Psych. 1994; 16:1-14. [Back to text]

10. BREDEMEIER $B$. Divergence in children's moral reasoning about issues in daily life and sport specific contexts. I J Sport Psych. 1995; 26:453-463. [Back to text]

11. BREDEMEIER BJ, SHIELDS DL. The utility of moral stage analysis in the investigation of athletic aggression. Soc Sport J. 1984; 1:138-149. [Abstract] [Back to text]

12. BRUSTAD RJ, BABKES ML, SMITH AL. Youth in sport: Psychological considerations. In: RN Singer, HA Hausenblas, CM Janelle (Eds.). Handbook of sport psychology. $2^{\text {nd }}$ ed. New York: John Wiley \& Sons; 2001. Pp. 604-635. [Back to text]

13. CALIFORNIA DEPARTMENT OF EDUCATION. State study proves physically fit kids perform better academically. News Release. Retrieved 23 November 2003, from http://www.cde.ca.gov/news/releases2002/rel37.asp. 2002. [Full text] [Back to text]

14. CAMACHO TC, ROBERTS RE, LAZARUS NB, KAPLAN GA, COHEN RD. Physical activity and depression: Evidence from the Alameda County Study. Amer J Epidem. 1991; 134:220-231. [Abstract] [Back to text]

15. CARRON AV, HAUSENBLAS HA, ESTABROOKS PA. The psychology of physical activity. New York: McGraw-Hill; 2003. [Back to text]

16. CHANTAL Y, BERNACHE-ASSOLLANT I. A prospective analysis of self-dermined sport motivation and sportspersonship orientations. Athletic insight. 2003; 51(4):11-18. [Full text] [Back to text]

17. COAKLEY JJ. Sport in society: Issues and controversies. 6th ed. Boston: McGraw-Hill; 1998. [Abstract] [Back to text]

18. COTE J. Coach and peer influence on children's development through sport. In: JM Silva, DE Stevens (Eds.). Psychological foundations of sport. Boston, MA: Allyn \& Bacon; 2002. Pp. 520-540. [Back to text] 
19. DANIELS E, SINCHAROEN S, LEAPER C. The relation between sport orientations and athletic identity among adolescent girl and boy athletes. J Sport Beh. 2005; 28:315-332. [Full text] [Back to text]

20. DWYER T, SALLIS JF, BLIZZARD L, LAZARUS R, DEAN K. Relation of academic performance to physical activity and fitness in children. Ped Exer Sc. 2001; 13:225-238. [Back to text]

21. EAGLY AH, CROWLEY M. Gender and helping behavior: A meta-analytic review of the social psychological literature. Psych Bul. 1986; 100(3):283-308. doi:10.1037/0033-2909.100.3.283 [Back to text]

22. EAGLY AH, WOOD W. Explaining sex differences in social behavior: A meta-analytic perspective. Pers Soc Psych Bul. 1991; 17:306-315. doi:10.1177/0146167291173011 [Back to text]

23. EITZEN DS, SAGE G. Sociology of North American sport. Dubugue, IA: Brown \& Benchmark publishers; 1997. [Back to text]

24. ELLEY D, KIRK D. Developing citizenship through sport: The impact of a sport-based volunteer programme on young sport leaders. Sport Educ Soc. 2002; 7(2):151-166. doi:10.1080/1357332022000018841 [Back to text]

25. ETNIER JI, SALAZAR W, LANDERS DM, PETRUZELLO SJ, HAN M, NOWELL P. The influence of physical fitness and exercise upon cognitive functioning: A meta-analysis. J Sport Exerc Psych. 1997; 19:249-274. [Back to text]

26. FARMER ME, LOCKE BZ, MOSCIKI EK, DANNENBERG AL, LARSON DB, RADLOFF LS. Physical activity and depressive symptoms: The NHANES I epidemiologic follow-up study. Amer $J$ Epid. 1988; 6:1340-1351. [Abstract] [Back to text]

27. FELTZ DL, LANDERS DM, RAIDER V. Enhancing self-efficacy in a high-avoidance motor task: A comparison of modeling techniques. J Sport Psych. 1979; 1:112-122. [Abstract] [Back to text]

28. GERDY J. Sport in school: The future of an institute. New York: Teachers College Colubmia; 2000. [Abstract] [Back to text]

29. GIULIANO TA, POPP KE, KNIGHT JL. Footballs versus barbies: Childhood play activities as predictors of sport participation by women. Sex Rol. 2000; 42:159-181. doi:10.1023/A:1007035122089 [Back to text]

30. GREENDORFER SL. Socialization processes and sport behavior. In: T Horn (Ed.). Advances in sport psychology. $2^{\text {nd }}$ ed. Champaign, IL: Human Kinetics; 2002. Pp. 377-401. [Back to text]

31. GUIVERNAU M, DUDA J. Moral atmosphere and athletic aggressive tendencies in young soccer players. J Moral Educ. 2002; 31(1):67-85. doi:10.1080/03057240120111445 [Back to text]

32. HARNE AJ, BIXBY WR. The benefits of and barriers to strength training among college-age women. J Sport Beh. 2005; 28:151-166. [Abstract] [Back to text]

33. HAYES SD, CROCKER PRE, KOWALSKI KC. Gender differences in physical self-perceptions, global self-esteem and physical activity: Evaluation of the physical self-perception profile model. $J$ Sport Beh. 1999; 22:1-14. [Full text] [Back to text]

34. HEALTH CANADA Canada's physical activity guide to healthy active living. Retrieved 10 May 2007, from http://www.hc-sc.ca/hppb/paguide/pdf/guideEng.pdf, 2003. [Full text] [Back to text]

35. HELLISON D. Teaching responsibility through physical activity. $2^{\text {nd }}$ ed. Champaign, IL: Human Kinetics; 2003. [Back to text]

36. KALLIOPUSKA M. Relation of empathy and self-esteem to active participation in Finnish baseball. Perc Motor Skil. 1987; 65:107-113. [Back to text]

37. KALLIOPUSKA M. Self-esteem and narcissism among the most and least empathetic Finnish baseball players. Perc Motor Skil. 1992; 75:945-946. [Abstract] [Back to text]

38. KELINSKE B, MAYER BW, CHEN KL. Perceived benefits from participation in sports: A gender study. Wom Manag Rev. 2001; 16:75-84. doi:10.1108/09649420110386601 [Back to text] 
39. KLEIBER DA, ROBERTS GC. The effect of sport experience in the development of social character: An exploratory investigation. J Sport Psych. 1981; 3:114-122. [Abstract] [Back to text]

40. KULL M. The relationship between physical activity, health status and psychological well-being of fertility-aged women. Scand J Med Sci Sports. 2002; 12:241-247. doi:10.1034/j.16000838.2002.00341.x [Back to text]

41. LEE IM. Physical activity, fitness and cancer. In: C Bouchard, RJ Shepard, T Stephens (Eds.). Physical activity, fitness and health: International. Proceedings and Consensus Statement. Champaign, IL: Human Kinetics; 1994. Pp. 814-831. [Back to text]

42. LICKONA T. Educating for character: How our schools can teach respect and responsibility. New York: Bantam Books; 1991. [Abstract] [Back to text]

43. MACINTYRE A. After virtue. London: Duckworth; 1981. [Back to text]

44. MANNELL RC, KLEIBER DA. A social psychology of leisure. State College, PA: Venture; 1997. [Back to text]

45. MANSON JE, RIMM EB, STAMPFER MJ, COLDITZ GA, WILLETT WC, KROLEWSKI AS, et al. Physical activity and incidence of non-insulin dependent diabetes mellitus in women. Lancet. 1991; 338:774-778. doi:10.1016/0140-6736(91)90664-B [Back to text]

46. MARCIA J, FRIEDMAN M. Ego identity status in college women. J Per. 1970; 38:248-263. doi:10.1111/j.1467-6494.1970.tb00007.x [Back to text]

47. MARKUS H, NURIUS P. Possible selves: The interface between motivation and self-concept. In: $K$ Yardley, T Honess (Eds.). Self and identity: Psychological perspectives. Suffolk: John Willey \& Sons; 1987. Pp. 157-172. [Back to text]

48. MILLER BW, ROBERS GC, OMMUNDSEN Y. Effect of perceived motivational climate on moral functioning, team moral atmosphere perceptions, and the legitimacy of intentionally injurious acts among competitive youth football players. Psych Sport Exer. 2005; 6:461-477. doi:10.1016/j.psychsport.2004.04.003 [Back to text]

49. MIZE M. Cognitive development: The physical education connection. Teach Elem Phys Educ. 1991; 2(1):14-15. [Back to text]

50. MURRAY MC, MANN BL. Leadership effectiveness. In: JM Williams (Ed.). Applied sport psychology. $4^{\text {th }}$ ed. Mountain View: Mayfield Publishing Company; 2001. Pp. 82-106. [Back to text]

51. NATIONAL FEDERATION OF STATE HIGH SCHOOL ASSOCIATION. The case for high school activities. Retrieved 5 February 2004, from http://www.nfhs.org/case.htm, 2002. [Full text] [Back to text]

52. NATIONAL RESEARCH COUNCIL AND INSTITUTE OF MEDICINE. Community programs to promote youth development. Washington: National Academy Press, 2002. [Full text] [Back to text]

53. NODDINGS N. Educating moral people. New York: Teachers College Press; 2002. [Abstract] [Back to text]

54. PALUSKA SA, SCHWENK TL. Physical activity and mental health: Current concepts. Amer J Epid. 2000; 29:167-180. [Abstract] [Back to text]

55. PARK N. The role of subjective well-being in positive youth development. Annals Amer Acad Pol Socl Sci. 2004; 59(1):25-39. doi:10.1177/0002716203260078 [Back to text]

56. PRAGER K. Identity status, sex-role orientation, and self-esteem in late adolescent females. J Gen Psych. 1983; 143:159-167. [Back to text]

57. PROIOS M, BALASAS D. Self-esteem as a moderator agent for the improvement of the adolescents' moral behavior. I J Phys Educ. 2007; 44(2):67-74. [Back to text]

58. PROIOS M, DOGANIS G, ATHANAILIDIS I. Moral development and form of participation, type of sport, and sport experience. Perc Motor Skil. 2004; 99:633-642. [Abstract] [Back to text] 
59. RAWLS J. Justice as fairness: A restatement. Cambridge, MA: Harvard University Press; 2001. [Back to text]

60. RIEMER BA, BEAL B, SCHROEDER P. The influences of peer and university culture on female student athletes' perceptions of career termination, professionalization, and social isolation. $J$ Sport Beh. 2000; 23:364-378. [Abstract] [Back to text]

61. ROGERS CR. Client centered therapy. Boston: Houghton Mifflin; 1951. [Back to text]

62. SAGE G. Orientations towards sport of male and female intercollegiate athletes. J Sport Psych. 1980; 2:355-362. [Back to text]

63. SAGE G. Orientations towards sport of male and female intercollegiate athletes. J Sport Psych J Phys Educ Recre Dance. 1998; 69(1):15-18. [Back to text]

64. SALONEN JT, PUSK P, TOUMILEHTO J. Physical activity and risk of myocardial infarction, celebral stroke and death: A longitudinal study in Eastern Finland. Amer J Epid. 1982; 115:526537. [Abstract] [Back to text]

65. SCANLAN TK, CARPENTER P, SCHMIDT G, SIMONS J, KEELER B. An introduction to the sport commitment model. J Sport Exerc Psych. 1993; 15:1-15. [Abstract] [Back to text]

66. SHIELDS D, BREDEMEIER B. Character development and physical activity. Champaign IL: Human Kinetics; 1995. [Back to text]

67. SHIELDS D, BREDEMEIER B. Moral development and behavior in sport. In: RN Singer, HA Hausenblas, CM Janelle (Eds.). Handbook of sport psychology. $2^{\text {nd }}$ ed. New York: Wiley \& Sons; 2001. Pp. 585-603. [Back to text]

68. SHOGAN D. The making of high-performance athletes: Discipline, diversity, and ethics. Toronto: University of Toronto Press; 1999. [Back to text]

69. STEPHENS T. Physical activity and mental health in the United States and Canada: Evidence from four population surveys. Prev Med. 1988; 17:35-47. doi:10.1016/0091-7435(88)90070-9 [Back to text]

70. STEVENS DA. Movement concepts: Stimulating cognitive development in elementary students. J Phys Educ Recre Dance. 1994; 65(8):16-23. [Abstract] [Back to text]

71. SULLIVAN HS. The interpersonal theory of psychiatry. New York: Norton; 1953. [Back to text]

72. TELAMA R. Moral development. In: YV Auweele, F Bakker, S Biddle, M Durand, R Seiler (Eds.). Psychology for physical educators. Champaign, IL: Human Kinetics; 1999. Pp. 321-342. [Back to text]

73. TSAI E \& FUNG L. Sportspersonship in youth basketball and volleyball players. Athl Ins. 2005; 51(4):37-46. [Full text] [Back to text]

74. WANKEL LM, BERGER BG. The psychological and social benefits of sport and physical activity. $J$ Leis Res. 1990; 22(2):176-182. [Abstract] [Back to text]

75. WEBB H. Professionalization of attitudes toward play among adolescents. In: GS Kenyon (Ed.). Sociology of sport. Chicago: The Athletic Institute; 1969. [Back to text]

76. WEINBERG R, GOULD D. Foundations of sport \& exercise psychology. $3^{\text {rd }}$ ed. Champaign, IL: Human Kinetics; 2003. [Back to text]

77. WEISS MR, SMITH AL. Moral development in sport and physical activity: Theory, research, and intervention. In: TS Horn (Ed.). Advances in sport psychology. $2^{\text {nd }}$ ed. Champaign, IL: Human Kinetics; 2002. Pp. 243-280. [Back to text]

78. WIGFIELD A, KARPATHIAN M. Who am I and What can I do? Children's self-concepts and motivation in achievement situations. Educ Psych. 1991; 26:233-261. [Abstract] [Back to text]

79. WRIGHT A, COTE J. Retrospective analysis of leadership development through sport. Sport Psych. 2003; 17:268-291. [Abstract] [Back to text] 
80. YOUNG J, BURSIK K. Identity development and life plan maturity: A comparison of women athletes and nonathletes. Sex Rol. 2000; 43:241-254. doi:10.1023/A:1007033031566 [Back to text] 